\title{
EDUCATION IN DIGITAL ERA BETWEEN ANALYSIS OF PREDICTABILITY AND CONSOLIDATION OF RESILIANCE
}

\author{
Romeo-Cătălin CREȚU ${ }^{a *}$, Irina-Daniela CIȘMAȘU ${ }^{b}$, Adrian ANICA-POPA ${ }^{c}$, \\ Petrică STEFAN ${ }^{d}$ \\ ${ }^{a, d}$ University of Agronomic Sciences And Veterinary Medicine of Bucharest, Romania \\ ${ }^{b, c}$ Bucharest University of Economic Studies, Romania
}

\begin{abstract}
The educational institutions and the entire education system were heavily affected by the Covid-19 pandemic, which forced us to adapt favourably to unfavourable conditions. During the crisis, educational practices were quickly reconfigured, from face-to-face work to the online environment. This has shown that teaching, learning and technology are part of an ecosystem, that of digital education.The aim of this research is to analyse and highlight the benefits and limits of the world's Massive Open Online Courses (MOOCs) systems and their implementation in Romania, facilitating the internationalization of higher education establishments. The objectives of the article are to investigate the relations between the elements provided by the sample of 67 courses conducted through the Coursera platform, in June 2020, the „Human skills” field. As research methods, the authors used descriptive methods, correlation coefficients, regression analysis and performed statistical tests using the SPSS program. The results of the research responded to the authors' assumptions that there are significant correlations and a certain degree of association between variables. The authors' conclusion is that we need to build together a new education system, based on modern technologies, based on digitalisation, adaptable, correlated with the labour market, that strengthens resilience and is predictable.
\end{abstract}

KEYWORDS: digital age, education, learning platform, predictability, resilience, technology.

\section{INTRODUCTION}

Who could have thought a year ago that we could be present anywhere, anytime, online? Over the past decade, technological development has seen a very great development (Saettler, 1968), and our next generation is already dependent on the internet and on-demand information, just a click away. The Internet of Things (IoT) affected the global educational institution a year ago, from nurseries, kindergartens, primary schools, secondary schools to high schools and universities.

This requires adapting the education system to new technologies. Experts have shown that new digital technologies (Kaplan \& Haenlein, 2016) must be used in the education system to make teaching more attractive and graduates competitive in the labour market. Until the Covid-19 crisis, the implementation of new technologies was done on a voluntary basis, with each country or university having its own strategy. After the crisis, it was necessary for face-to-face activities to be transferred online. It was a challenge for all categories involved: teachers, students and parents. Some had basic digital concepts or had very few. A major problem facing the education system (Curaj \& others, 2020) was access to the internet infrastructure, but also the lack of a computer, laptop, tablet or mobile phone from the equipment of the parties involved.

\footnotetext{
* Corresponding author. E-mail address: creturomeocatălin@yahoo.com
} 
Building on these realities, specialists believe that better cooperation is needed, between all the actors involved, to achieve a modern school that uses digital technologies - „SMART-Edu Modern Accessible School based on Digital Resources and Technologies" and meets the following needs: accessibility, connectivity, community, digital educational ecosystem, innovation and sustainability. We need to build together a new, modern, digitalised education system that is adaptable, linked to the demands of the labour market, that strengthens resilience and is predictable Resilience is the ability of people (Greitens, 2017) to adapt favourably to adverse situations. Since the 1960s, the term has undergone several changes. Initially, it was thought to be a characteristic with which the human being was born, then the individual, social, familiar, and cultural factors were analyzed. Lately, specialists have proposed changing the term of resilience in resilient processes. Studies show that resilience is a real process, involving several factors: family, friends, environment, economic situation. Predictability is defined by actions, facts or normative acts that can be anticipated by specialists, business environment, citizens.

A person is predictable when one can predict his or her behaviour in the future on the basis of previous studies. In the case of the human-computer interaction study, predictability refers to predicting the consequences of a user action (Diebold \& Kilian, 2001), based on the current state of the system. Today, in a world affected by the Covid-19 pandemic, the analysis of the predictability of the education system in Romania is necessary to be done urgently because the future is of the digital age, and the new skills and abilities acquired by young people are based on specializations, curricula, courses, disciplines, syllabus (Downes, S., 2008), adapted correctly and as quickly as possible to the labour market and the trades of the future. People, but especially young people, have the ability to adapt favourably to adverse situations and resist new changes. Research in the field (Saettler,1968) shows that between 1890 and 1920 distance education was born, first course by correspondence and then on radio and television. In the 2000s, with the expansion of the Internet, distance education developed, by increasing its online presence, as well as by developing MOOC, which is an online course with unlimited participation and open access via the Internet. It offers interactive courses (Bell, 2011) with user forums to help community interactions among students and teachers, as well as immediate feedback on quick questions and themes. MOOCs are a new development of distance education (Yousef et al., 2015), which was introduced in 2006 and has developed since 2012. The term MOOC was invented in 2008 by Dave Cormier of Prince Edward Island University as a result of a course called Connectivism and Knowledge Connective (also known as CCK08).

In addition, other e-learning platforms have emerged: Khan Academy, Udemy and Alison. As MOOCs developed, different conceptions of the platform emerged: some focused on a connectivist philosophy and others on traditional courses (Creţu et al, 2013). Specialists have proposed two terms „,CMOOC" and „xMOOC" to make a difference. The „Chronicle of Higher Education” conducted a survey among teachers who taught MOOC, on a sample of 103 respondents. The conclusion was that the teachers spent over 100 hours before starting the teaching with the realization of the necessary teaching materials, and between 8 and 10 hours per week for feedback on the topics proposed on the forums. The results of these efforts were quantified in the large number of students enrolled in the course, about 33,000, but only 2,600 passed, and the teacher was assisted in the course by 1 assistant teacher. Compared to traditional courses (Șerban et al, 2020), online courses are time consuming and require additional skills offered by IT specialists, videographers, e-learning platform specialists, who use cloud computers and educational software (Lectora, Elicitus, etc.). Courses taught in the MOOC (Pappano, 2014) system must meet online learning standards. From the reports of the technology teachers for the creation of the MOOC courses, it results that at least 19 people are needed to work from the idea phase of the course to teaching and evaluation. The aim of this research is to analyze the benefits of online education systems in the world and their implementation on a large scale in Romania. Through the participation of Romanian universities in the Coursera platform, the internationalization and 
adaptation of the courses offered in the digital age, to the new skills and abilities required on the labor market, in the current context of the Covid-19 pandemic, which involved rapid change (back with 9 months) to the online education system with synchronous or asynchronous teaching.

The paper contains (Dinu et al., 2017) four sections: presentation of the concept of online courses through the Coursera platform in the literature; research methodology for investigating the correlations between elements and the degree of association of variables; results and discussions based on research and research conclusions, limits and directions. The authors investigated the relationships between the elements provided by the Coursera database, in June 2020, on a sample of 67 courses offered for one of the five fields, namely the field „Human skills”, using the program SPSS (Statistical Package for the Social Sciences), for statistical processing.

\section{ONLINE COURSES IN THE LITERATURE REVIEW}

According to the New York Times, 2012 (Pappano, 2014) was declared the MOOC year due to the emergence of a large number of providers in this field, very well positioned financially, associated with well-rated universities in the United States, including Coursera, Udacity and edX (Hey, 2016). Since 2013, many prestigious universities on all continents have slowly but surely joined this type of learning, as if anticipating the coronavirus pandemic, which was to appear at the end of 2019 and affect the entire population. of the globe. Therefore, we are witnessing the birth of a new industry (Adamopoulos, 2013) with a complex structure, „consisting of MOOC suppliers, companies, universities, non-profit organizations, society, other stakeholders" (Annex no. 1). Stanford University launched in 2011 the first online course on „Introduction to Artificial Intelligence”, a course launched by Sebastian Thrun and Peter Norvig, which managed to gather 160,000 students. Soon Andrew Ng and Jennifer Widom launched two more courses, much appreciated among the participants. Following the recorded results, the 2 big companies in this industry appeared, namely Udacity (Carr, 2013), founded by Thrun and Coursera founded by Daphne Koller and Andrew Ng. The Massachusetts Institute of Technology (MIT) created in 2012 MITx, a non-profit company, and launched the first 6002x course, ,which later joined 2 other prestigious universities, namely Harvard University and Berkeley University, and the name of the group has been changed to edX". EdX has partnered with Google. Tsinghua University, which uses its own platform, has joined this consortium. In 2013 alone, EdX offered 94 courses offered by 29 universities around the world.

The consortium grew stronger with the addition of other prestigious universities, Stanford University, whose Class2Go platform merged with edX and created the XBlock SDK, a common open source platform. Coursera Company, which developed its own platform, offered „325 courses by March 2013, of which 30\% in science, 28\% in arts and humanities, 23\% in information technology, $13 \%$ in business and 6\% in mathematics". Udacity offered 26 courses at that time. The number of courses has increased a lot since then: in „2016, edX offered 820 courses, Coursera 1,580 courses and Udacity over 120 courses". The most popular courses on the Coursera platform are ,psychology and philosophy”, where student feedback and high completion rates show that they are as good as math and science courses.

According to FutureLearn, the agreement between the International English Language Testing System (IELTS) and the British Council for English language tests has led to the enrollment of over 440,000 students. Very quickly, the first innovative courses appeared (Downes, 2008), respectively „CMSO, CCK08 and ds106”, which focus on digital storytelling. Other universities launch their own platforms, such as: University of Helsinki ,which offers programming courses for more than 8,000 participants, Galileo University launched" in 2012 the first MOOC in Latin America, Ball State University, taught the course „The genre through comic books” University of Miami launched in 2012 the first MOOC high school, with a biology profile, for students (Vihavainen et al., 2012) students in the discipline of biology, Duke University launched the course of Social Sciences and Literature, University of Carolina launched Skynet University in 2013, which offers introductory 
astronomy courses to MOOC students. In July 2013, the University of Tasmania launched the „Understanding Dementia” course „which had a completion rate of 39\%”. Recognized by Nature magazine, Hong Kong University of Science and Technology launches the first MOOC in Asia. The first steps in physiotherapy were made in the UK, when Physiopedia launched the first MOOC related to professional ethics, in collaboration with Western Cape University in South Africa, and MIT and Stanford University initiated MOOC courses in Computer Science and Electrical Engineering. In 2013, Coursera „launched the first free e-books for several courses, in partnership with an online textbook rental company Chegg". So, 2013 is the year in which most courses are launched, as the first appearance from robotics to physics, from biology to statistics, from finance to psychology. In 2014, the „first paid master's degree in IT services $(\$ 7,000)$ was launched by the Georgia Institute of Technology".

The first business courses were used to use „case studies in the company, along with university research, to demonstrate that people and innovation are the key to success", according to the MOOC FutureLearn in the UK. If 2015 is the debut year of the online courses in medicine and art, offered by the University of Cape Town, on the Futurelearn platform, but also of the first MOOC (OpenClassrooms) bachelor's degrees in multimedia project management, 2018 is the year of the first course game on edX , from Brown University. Over „1.5 million people were enrolled in courses through the Coursera, Udacity or edX platforms by 2012". There was a record enrollment in 2013, when the Coursera platform enrolled ,approximately 2.8 million students, and in October 2013 exceeded 5 million, while edX reached 1.3 million”. The first studies on students appear at Stanford University, which shows that the number of men enrolled is higher than the number of women. The problem arises for students who do not speak English as their mother tongue. The possibility of subtitling courses in almost all spoken languages was created. MOOCs face school dropout (Prpić et al., 2015), according to analyzes conducted by Katy Jordan in 2015, the number of students enrolled is very high, but completion rates drop to 3-5\%, according to Coffrin et al., In 2012, at 7-9\%, after Coursera. However, experts say that the average MOOC completion rate is not a relevant, sufficiently objective indicator. According to Russian researchers Semenova, T. V. and Rudakova, L. M (2016), there are three important factors that determine school dropout: education, gender and MOOC experience. Approximately $18 \%$ of students with higher education complete the online course, while only $3 \%$ of those with secondary education complete, and of those who graduated the course, $65-80 \%$ have at least one experience of using the online learning platform. The percentage of men who attend the courses is 6-7 percent higher than that of women, who also take care of the family. Completion rates for online courses are lower than for traditional courses. The issue of MOOC efficiency remains a topic that needs to be addressed. The design of the training is different for MOOC courses compared to traditional ones. A MOOC course is designed to be ,a challenge” according to Thrun, ,without lecture, and the duration of a video should not be longer than 6-9 minutes". A combination of traditional and online learning methods (hybrid methods) can improve student performance.

The same cannot be said for online evaluations (Parr, 2013), which are different from the classic ones. Exams can be scheduled at regional testing centers or can be given at home or in the office, using webcams or monitoring mouse clicks. Studies in the state of Virginia show that $32 \%$ of students failed to adapt and withdrew from online courses, compared to $19 \%$ withdrawals from traditional courses. The mentoring system (Alraimi \& others, 2015) could „,be used to reduce the dropout phenomenon as well as the use of techniques to maintain the connection with students". In terms of information architecture, courses for synchronous learning are different from courses for asynchronous learning.

In conclusion, MOOCs are seen as an engine of the new education industry in higher education (The Chronicle of Higher Education, 2021). Experts say that many services offered in traditional universities will become separate and sold to students individually or in new packages. 


\section{RESEARCH METHODOLOGY}

The year 2020 was a year marked by the Covid-19 pandemic and, at the same time, by the need to improve online teaching. In order to increase the international visibility of the activity of prestigious Romanian universities, the access of institutions, students and professors to the online academic platform Coursera (North American educational technology company) for Campus (Silicon Valley Mountain View, California, USA) was facilitated. In April 2020, the Coursera platform „offered online courses in various fields of interest for 68 million registered students, all exclusively online, with certification, professors from over 165 universities, over 40 partner industries and over 6,900 employees in business, government (Annex no.2)". Coursera is a „global educational platform, initiated by two Stanford University professors, Andrew Ng and Daphne Koller, which offers free courses for everyone". By June 2020, more than 5 million students worldwide have studied at least one course on this platform, free of charge. The courses offered on this platform (Annex no. 3) are from all fields (mathematics, accounting, biology, medicine, tourism, computers, cyber security, sales, marketing, geology, etc.). In March 2020, when the Covid-19 epidemic began, Coursera initiated collaborations with universities around the world to improve its online performance. The data provided by the Coursera platform in June 2020 (Annex 4) are relevant, namely „over 10,000 online study programs launched, with 1.3 million students enrolled in these programs, 7.5 million enrollment in courses and over 20 million hours of virtual learning environment". The Campus Coursera program currently includes ,28 universities (Annex 5) from 5 EU Member States (HEC Paris, INSEAD, ENS, Sciences Po Paris, ESCP Business School, Imperial College London, ESSEC Business School, Copenhagen Business School, University of Copenhagen, Lund University, Sapienza University of Rome, Bocconi University of Milan, Erasmus University of Rotterdam)". The approach of this research consists in analyzing and highlighting the benefits of online education systems in the world and their widespread implementation in Romania. By participating as many prestigious universities in Romania as possible in the Coursera academic platform, a major goal can be achieved, that of internationalization, by adapting the curricula offered in the digital age to the new skills needed on the labor market, which has been severely affected. in the last period. It is very important that universities during this period adapt their curricula to the new requirements imposed by Covid - 19, in the context of the growing need for jobs that require relevant skills. In addition to these, 300 million full-time jobs are at risk due to the economic impact of the pandemic. It is expected that „42\% of jobs will have a completely different qualification by 2022 , a lower percentage, $50 \%$ of employers believe that universities are preparing students to meet the new demands of the labor market and only $9 \%$ of principals say that their leaders have the necessary digital skills", according to the report World Economic Forum Jobs of the Future Report; Deloitte, International Labor Organization, World Economic Forum: Digital Transformation.

The Coursera platform provides a wide range of information for June 2020, on five areas of interest, namely ,business, technology, data, human skills, industry”, according to the table below:

Table 1. Number of courses offered through the Coursera platform

\begin{tabular}{|l|l|}
\hline Coursera & Nr. courses offered \\
\hline Bussines & 978 \\
\hline Technology & 828 \\
\hline Date & 658 \\
\hline Human Skills & 67 \\
\hline Industry & 1.143 \\
\hline Total & $\mathbf{3 . 6 7 4}$ \\
\hline
\end{tabular}

Source: Coursera Platform, adaptation by authors (June 2020) 
The name and number of industries broken down by category is shown in the figure below. The first place is occupied by the health and life sciences industry, followed by professional services, technology, public sector, etc.

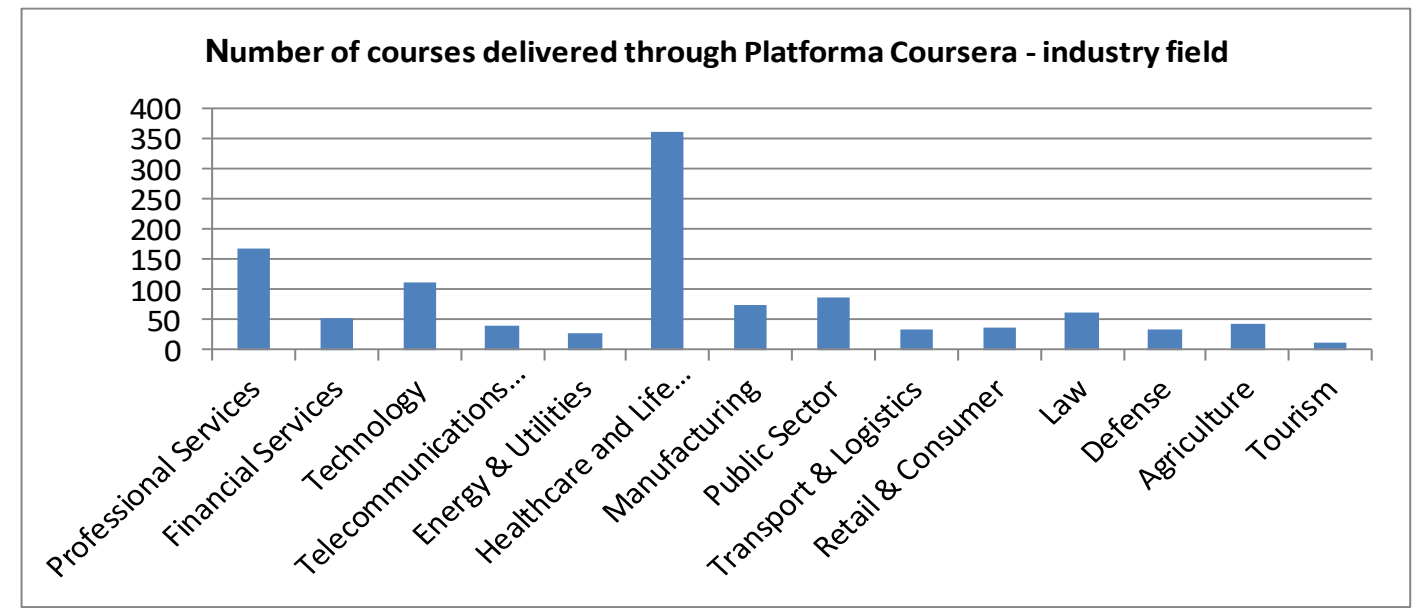

Figure 1. Courses - industry - Coursera

Source: Coursera Platform, adaptation by authors (June 2020)

The purpose of the research is to investigate the relationships between the elements provided by the database of the academic platform Coursera, in June 2020, on the field "Human skills". The authors used the SPSS program for statistical processing. The data provided by the Coursera platform for the 67 courses are: skills, acquired skills, course name, university/partner industry, level of difficulty, average number of hours, course evaluation, course link, course description, specialization, specialization link, interval hours, subtitle language, course language, domain, subdomain, course ID (Annex no. 6).

The number of students enrolled in the first 10 courses, in the field "Human skills", according to the evaluation of the course is surprising: from 9,711 to $2,676,601$ students.

Table 2. Top 10 courses according to the evaluation criterion of the course and the number of enrolled students

\begin{tabular}{|c|c|c|c|c|c|c|c|}
\hline 这 & $\overline{\bar{n}}$ & 递 & 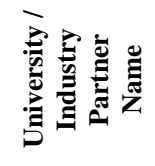 & 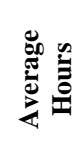 & 总 & 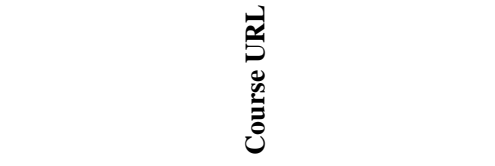 & 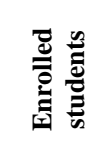 \\
\hline $\begin{array}{c}\text { Human } \\
\text { Skills }\end{array}$ & $\begin{array}{c}\text { Conflict } \\
\text { Management }\end{array}$ & $\begin{array}{l}\text { Negotiation skills: } \\
\text { Negotiate and resolve } \\
\text { conflict }\end{array}$ & $\begin{array}{l}\text { Macquarie } \\
\text { University }\end{array}$ & 14.4 & 5 & $\frac{\text { https://www.coursera.org/learn/negotiation }}{\underline{\text {-skills-conflict }}}$ & 11.952 \\
\hline $\begin{array}{c}\text { Human } \\
\text { Skills }\end{array}$ & Negotiating & $\begin{array}{l}\text { Negotiation skills: } \\
\text { Negotiate and resolve } \\
\text { conflict }\end{array}$ & $\begin{array}{l}\text { Macquarie } \\
\text { University }\end{array}$ & 14.4 & 5 & $\frac{\text { https://www.coursera.org/learn/negotiation }}{\text {-skills-conflict }}$ & 11.952 \\
\hline $\begin{array}{c}\text { Human } \\
\text { Skills }\end{array}$ & Adaptability & $\begin{array}{l}\text { Adapt your } \\
\text { leadership style }\end{array}$ & $\begin{array}{l}\text { Macquarie } \\
\text { University }\end{array}$ & 18.2 & 4.92 & $\frac{\text { https://www.coursera.org/learn/leadership- }}{\text { adapt-your-style }}$ & 16.038 \\
\hline $\begin{array}{c}\text { Human } \\
\text { Skills }\end{array}$ & Communication & $\begin{array}{c}\text { Multimodal } \\
\text { Literacies: } \\
\text { Communication and } \\
\text { Learning in the Era } \\
\text { of Digital Media }\end{array}$ & $\begin{array}{l}\text { University } \\
\text { of Illinois } \\
\text { at Urbana- } \\
\text { Champaign }\end{array}$ & 15.3 & 4.91 & $\frac{\underline{\text { https://www.coursera.org/learn/multimoda }}}{\underline{\text { 1-literacies }}}$ & 9.711 \\
\hline $\begin{array}{c}\text { Human } \\
\text { Skills }\end{array}$ & Adaptability & $\begin{array}{l}\text { Introduction to Self- } \\
\text { Determination } \\
\text { Theory: An approach } \\
\text { to motivation, } \\
\text { development and } \\
\text { wellness }\end{array}$ & $\begin{array}{l}\text { University } \\
\text { of } \\
\text { Rochester }\end{array}$ & 13.4 & 4.91 & $\frac{\text { https://www.coursera.org/learn/self- }}{\text { determination-theory }}$ & 29.803 \\
\hline
\end{tabular}




\begin{tabular}{|c|c|c|c|c|c|c|c|}
\hline 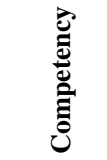 & $\overline{\bar{\nabla}}$ & 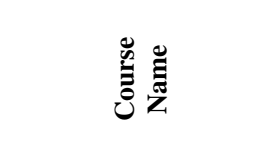 & 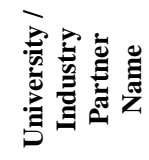 & 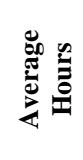 & 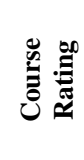 & 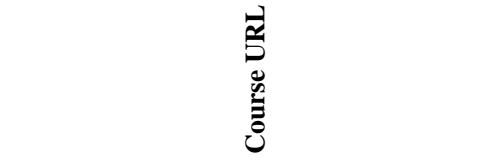 & 总 \\
\hline $\begin{array}{l}\text { Human } \\
\text { Skills }\end{array}$ & Resilience & $\begin{array}{l}\text { Build personal } \\
\text { resilience }\end{array}$ & $\begin{array}{l}\text { Macquarie } \\
\text { University }\end{array}$ & 12 & 4.9 & $\frac{\text { https://www.coursera.org/learn/build- }}{\text { personal-resilience }}$ & 24.890 \\
\hline $\begin{array}{l}\text { Human } \\
\text { Skills }\end{array}$ & Critical Thinking & $\begin{array}{l}\text { Think Again III: How } \\
\text { to Reason Inductively }\end{array}$ & $\begin{array}{l}\text { Duke } \\
\text { University }\end{array}$ & 14 & 4.85 & $\frac{\text { https://www.coursera.org/learn/inductive- }}{\text { reasoning }}$ & 30.973 \\
\hline $\begin{array}{l}\text { Human } \\
\text { Skills }\end{array}$ & Creativity & $\begin{array}{l}\text { Strategic Innovation: } \\
\text { Building and } \\
\text { Sustaining Innovative } \\
\text { Organizations } \\
\end{array}$ & $\begin{array}{l}\text { University } \\
\text { of Illinois } \\
\text { at Urbana- } \\
\text { Champaign }\end{array}$ & 15 & 4.81 & $\frac{\frac{\mathrm{https}: / / \text { www.coursera.org/learn/strategic- }}{\text { innovation-building-and-sustaining- }}}{\text { innovative-organizations }}$ & 34.054 \\
\hline $\begin{array}{l}\text { Human } \\
\text { Skills }\end{array}$ & Collaboration & $\begin{array}{l}\text { Introduction to } \\
\text { Negotiation: A } \\
\text { Strategic Playbook } \\
\text { for Becoming a } \\
\text { Principled and } \\
\text { Persuasive Negotiator }\end{array}$ & $\begin{array}{c}\text { Yale } \\
\text { University }\end{array}$ & 26.8 & 4.81 & https://www.coursera.org/learn/negotiation & 326,445 \\
\hline $\begin{array}{l}\text { Human } \\
\text { Skills }\end{array}$ & Negotiating & $\begin{array}{l}\text { Introduction to } \\
\text { Negotiation: A } \\
\text { Strategic Playbook } \\
\text { for Becoming a } \\
\text { Principled and } \\
\text { Persuasive Negotiator }\end{array}$ & $\begin{array}{c}\text { Yale } \\
\text { University }\end{array}$ & 26.8 & 4.81 & https://www.coursera.org/learn/negotiation & 326,445 \\
\hline $\begin{array}{l}\text { Human } \\
\text { Skills }\end{array}$ & Adaptability & $\begin{array}{l}\text { Learning How to } \\
\text { Learn: Powerful } \\
\text { mental tools to help } \\
\text { you master tough } \\
\text { subjects }\end{array}$ & $\begin{array}{l}\text { University } \\
\text { of } \\
\text { California } \\
\text { San Diego }\end{array}$ & 11.8 & 4.8 & $\frac{\text { https://www.coursera.org/learn/learning- }}{\text { how-to-learn }}$ & $2,676.601$ \\
\hline
\end{tabular}

Source: Coursera Platform, adaptation by authors(June 2020)

To achieve the research goal, we investigated the following 10 nonnumerical variables from the Coursera database, June 2020, for the "Human skills" area of competence: ability, university/industry partner, course name, course description, specialization, acquired skills, specialization description, language subtitling, domain and subdomain. In this field we have identified:

Skills such as: Adaptability, Communication, Collaboration, Creativity, Critical Thinking, Conflict Management, Emotional Intelligence, Learning, Teamwork, Negotiation, Resistance, Problem Solving, etc.;

$\checkmark$ offered in the 67 courses, of which we mention: Multimodal literacy: Communication and learning in the digital media era, Communication strategies for a virtual age, Design thinking for innovation, Strategic innovation: Building and supporting innovative organizations, Creative collaboration, Change Perspectives, Creative Thinking: Techniques and Tools for Success, Critical Thinking for the Information Age, Thinking Model, Intelligence Tools for the Digital Age, Thinking Again I: Understanding Arguments, Delivering Useful Feedback, Inspiring Leadership Through Intelligence Emotional, Influencing People, Inspiring and Motivating Individuals, Exploring Emerging Technologies for Successful Lifelong Learning, Introduction to Learning and Lifelong Learning Transfer, Mindshift: Break Through Barriers to Learning and Discovering Hidden Potential, Problem assessment, Build personal resilience;

$\checkmark$ grouped on 3 teaching levels (beginners, intermediate, advanced);

$\checkmark$ the courses are delivered by prestigious universities, such as: Macquarie University, University of Illinois at Urbana-Champaign, Duke University, Yale University, University of California San Diego, University of Colorado Boulder, University of Geneva, University of Michigan, University of Washington, UNSW Sydney (The University of New South Wales), ESSEC Business School, National Research University Higher School of Economics, IESE Business 
School, Imperial College London, ESSEC Business School, Rice University, HEC Paris, University of Toronto, University of Rochester, etc .;

$\checkmark$ grouped by specializations: Human Resource Management and Leadership, Organizational Leadership, Innovation: From Creativity to Entrepreneurship, Business English for Non-Native Speakers, Communication Skills for Engineers, Dynamic Public Speaking, Influencing: Storytelling, Change Management and Governance, Entrepreneurship: Launching an innovative business, Innovation: From creativity to entrepreneurship, Top people and teams, Adaptation: Career development, etc.;

$\checkmark$ in fields such as: Business, Social Sciences, Life Sciences, Personal Development, Language Learning, Arts and Humanities;

$\checkmark$ and sub-domains such as: Essentials for business, Leadership-and-management, Education, Psychology, Personal development, Marketing, Economics, Learning-English, Entrepreneurship, Music and art, Business strategy;

$\checkmark$ the courses are taught in English, and the subtitling is done in the following languages: French, Italian, Vietnamese, Russian, Portuguese, Persian, Hebrew, Arabic, Spanish, Estonian, Romanian, Polish, Dutch, German, Chinese, Greek, Ukrainian, Hungarian, Serbian, etc..

The objectives of the research are to investigate the relationship between the following elements: skills and field; university/partner industry and course description; course name and field; specialization and skills acquired; specialization and description of specialization; domain and subdomain. It is expected that there will be strong, moderate, weak or zero correlations between the above mentioned variables and an acceptable or strong degree of association, according to Colton's rules.

We intend to test the following research hypotheses:

Hypothesis 1. There is a correlation between the specialization and the description of the specialization.

Hypothesis 2. There is a correlation between the university/partner industry and the course description.

As methods of analysis, we will use descriptive methods, correlation coefficients, regression analysis and perform statistical tests necessary to ensure high accuracy of results. Statistical processing is performed using the SPSS statistical program. For this stage of our research we will use coding as a tool for measuring variables that are continuous and normally distributed.

\section{RESULTS AND DISCUSSIONS}

According to Hypothesis 1, the Pearson correlation coefficient (figure no. 2) shows statistically significant results between specialization and specialization description, the correlation coefficient resulting in the table is positive, amounting to 0.643 , which reflects a moderate correlation, with a good degree of association, at a degree of significance of $1 \%$, on a sample of 67 observations.

We will further check if there is a link between the dependent variable - Specialization Description and the independent variable - Specialization. We choose as a graphical representation, the Simple Scatter Diagram.

From the figure 3 we can see a relatively correlated arrangement of the two variables, at an R2 = 0.414 . This means that on average, $41.4 \%$ of the variation in the description of the specialization can be explained by the specialization, on the sample analyzed, in June 2020, in the Covid-19 pandemic. 


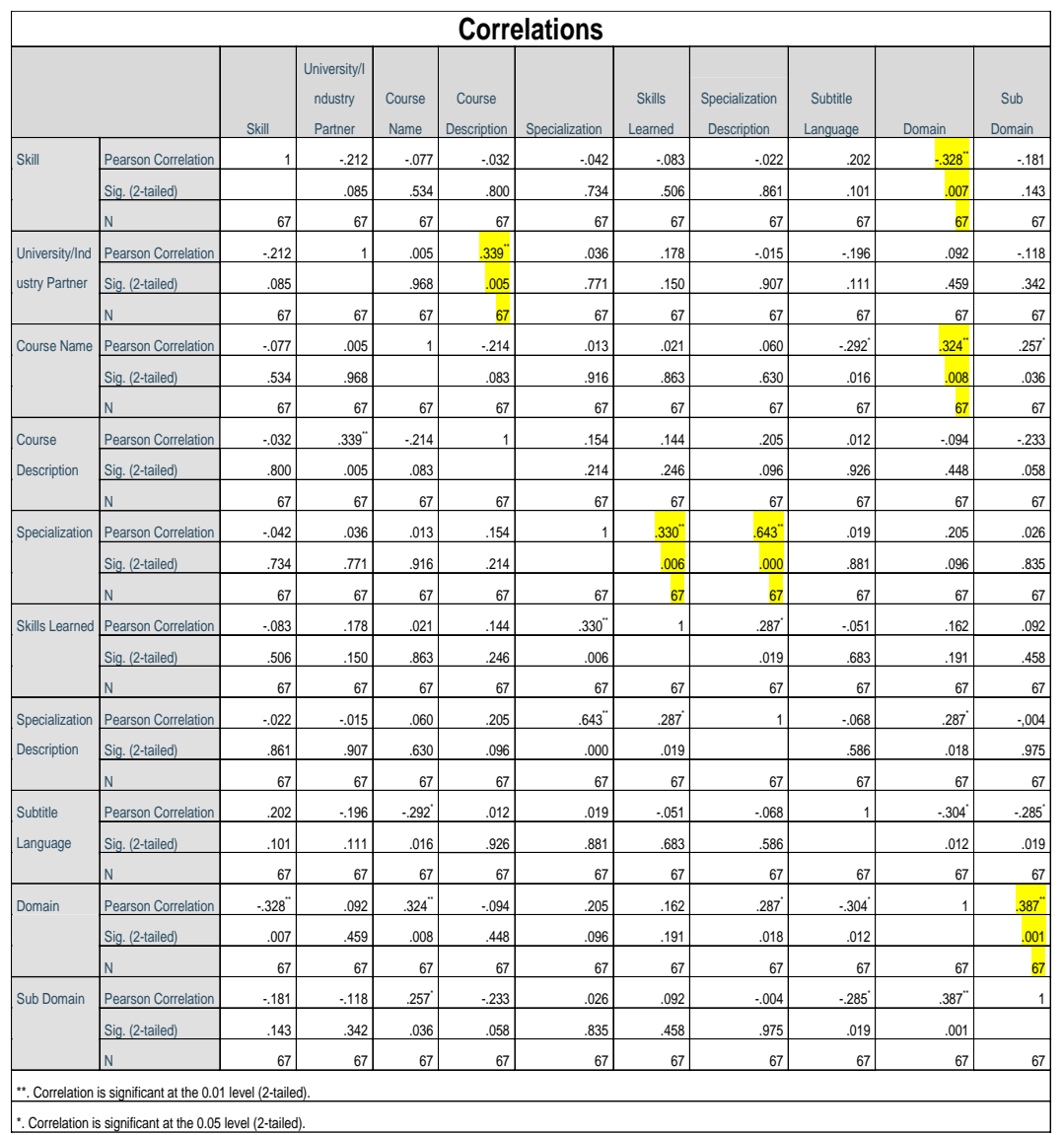

Figure 2. Pearson correlation coefficients

Source: Developed by the authors in the SPSS program

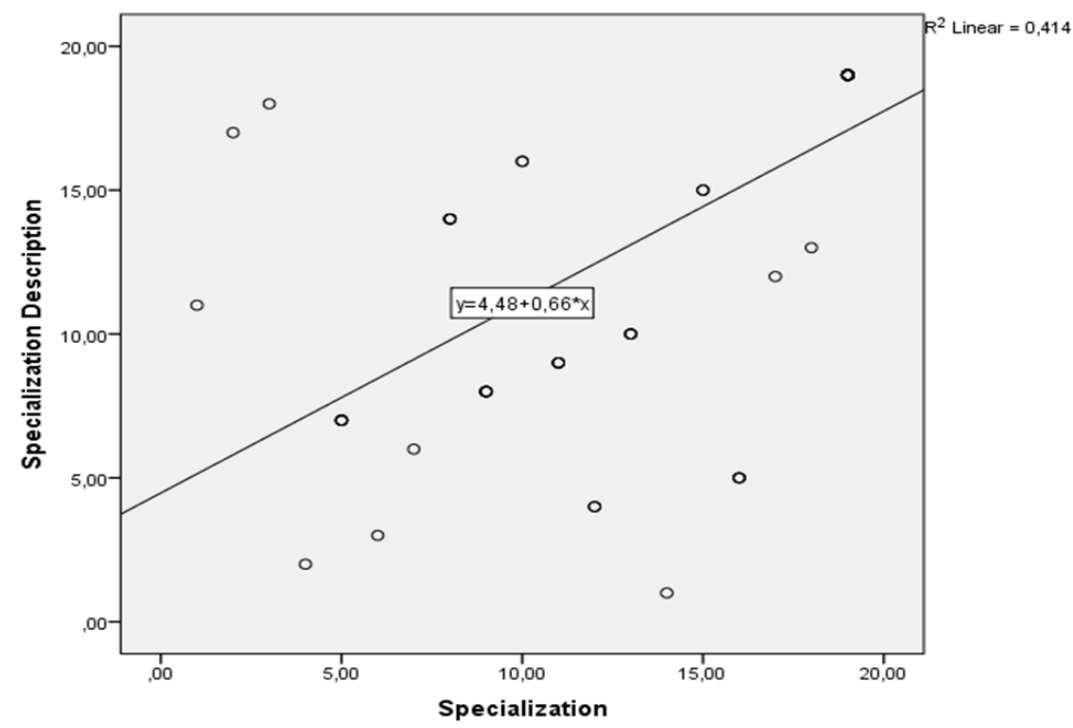

Figure 3. Simple Scatter Diagram

Source: Developed by the authors in the SPSS program

In order to establish the simple linear regression, we will present in the figure 4, the descriptive statistics, respectively the mean and the standard deviation for the dependent variable and the independent variable. 


\begin{tabular}{llll} 
Descriptive Statistics & Mean & Std. Deviation & N \\
\hline Specialization Description & 13.7164 & 5.81744 & 67 \\
\hline Specialization & 13.9254 & 5.63892 & 67 \\
\hline
\end{tabular}

Figure 4. Descriptive statistics

Source: Developed by the authors in the SPSS program

The following table (figure 5) highlights the Pearson correlation, which shows a correlation of $64.3 \%$, a relatively good correlation, which means that we chose the model relatively correctly, at a significance level of $1 \%$, on a sample of 67 observations:

\begin{tabular}{|c|c|c|c|}
\hline \multicolumn{4}{|l|}{ Correlations } \\
\hline & & Description & Specialization \\
\hline \multirow[t]{2}{*}{ Pearson Correlation } & Specialization Description & 1.000 & .643 \\
\hline & Specialization & .643 & 1.000 \\
\hline \multirow{2}{*}{ Sig. (1-tailed) } & Specialization Description & & .000 \\
\hline & Specialization & .000 & \\
\hline \multirow[t]{2}{*}{$\mathrm{N}$} & Specialization Description & 67 & 67 \\
\hline & Specialization & 67 & 67 \\
\hline
\end{tabular}

Figure 5. Pearson correlations

Source: Developed by the authors in the SPSS program

We will continue with the estimation of the model, and we will present the ANOVA table, which shows us if the model is relevant, respectively if the parameters of the regression equation differ significantly from zero. Because sig. (0.000) is less than 0.005 the risk threshold we assume in this case, means that the model is statistically relevant.

\begin{tabular}{|c|c|c|c|c|c|c|}
\hline \multicolumn{7}{|c|}{ ANOVA $^{\mathrm{a}}$} \\
\hline Model & & Sum of Squares & df & $\begin{array}{l}\text { Mean } \\
\text { Square }\end{array}$ & $\mathrm{F}$ & Sig. \\
\hline \multirow[t]{3}{*}{$\overline{1}$} & Regression & 924,073 & 1 & 924,073 & 45.867 & $.000^{\mathrm{b}}$ \\
\hline & Residual & $1,309.539$ & 65 & 20.147 & & \\
\hline & Total & $2,233.612$ & 66 & & & \\
\hline
\end{tabular}

Figure 6. ANOVA test

Source: Developed by the authors in the SPSS program

Next we analyze the table with coefficients and estimate a regression model with a constant. The estimate for the beta parameter, regarding the independent variable is statistically significant, because it has a sig. below $5 \%$ and the confidence interval $(0.488-0.859)$, does not contain the value zero. 


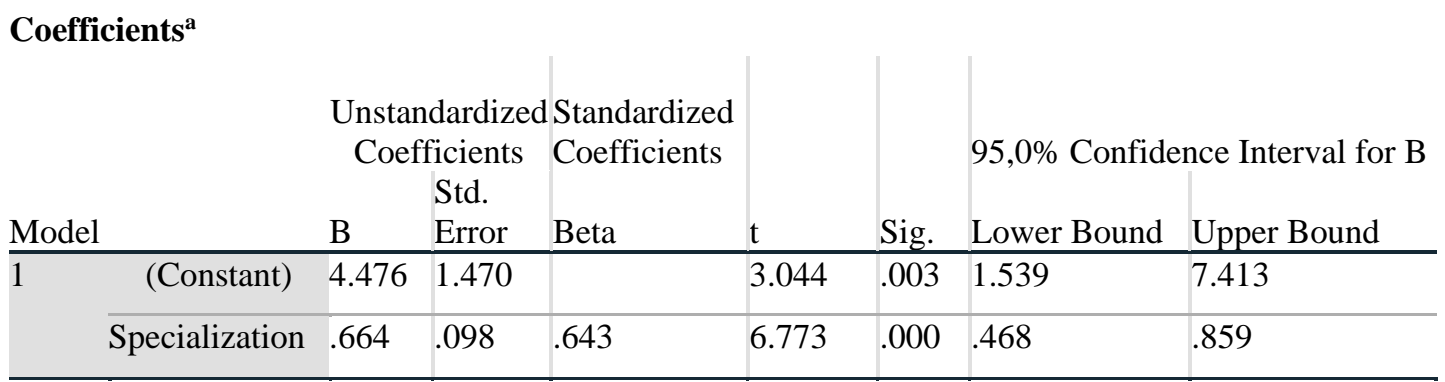

a. Dependent Variable: Specialization Description

Figure 7: Coefficients of the regression equation

Source: Developed by the authors in the SPSS program

According to Hypothesis 1, there is a positive relationship between specialization and the description of specialization, amounting to 0.643 , which reflects a moderate correlation with a good degree of association, at a significance level of $1 \%$, on a sample of 67 observations, field of interest "Human Skills". This means that the description of specialization must be well-argued with elements adapted to the new requirements of the labor market, so that young people from any region of the planet can choose, according to needs, the course or specialization that they recommend as having the necessary skills and abilities. finding a job in the digital age.

According to hypothesis 2, the Pearson correlation coefficient between the university / partner industry and the course description shows a weakly positive correlation $(r=0.339)$ and an acceptable degree of association. A positive Pearson correlation coefficient $(r=0.387)$ between domain and subdomain also means a weak correlation and a certain degree of association.

\section{CONCLUSIONS, LIMITS AND RESEARCH DIRECTIONS}

The presented study is intended to be only a starting point for more advanced studies on the investigation of variables offered by other areas of interest, the Coursera platform, where the number of courses (table no. 1) offered is much higher than the analyzed area. (Human skills), respectively, industry, business, technology, data, to adapt the Romanian education system to the online education system in the world. In addition, it is opportune for prestigious Romanian universities to make themselves known worldwide, to internationalize and adhere to the benefits of the online learning system by using MOOC platforms. It is very important that universities in this period adapt their own curricula to the new requirements imposed by Covid-19, in the context of the growing need for jobs that require relevant skills.

We are witnessing the establishment of a new industry in the field of education with a complex structure (Annex no. 1), consisting of MOOC providers, companies, universities, non-profit sector, venture capital, society, other stakeholders. Like any new learning model, it has benefits, but also limits.

The benefits of MOOCs include online collaboration, which facilitates the collaboration of students and teachers around the world without meeting physically, as well as partnerships between students, no matter where they are, without the need for transportation and accommodation; Increasing access to quality higher education for many people in developing countries; Providing an accessible alternative to formal education, addressing a large number of participants anywhere, who can study at any time, if they have an internet connection; The goals of sustainable development refer to a form of open education; It offers a flexible learning program, depending on time and space.

Through this new learning model, many introductory courses are free, with students paying a small fee, only for intermediate, advanced and accreditation courses.

Online course providers may charge employers for recruiting students. Students may pay fees for taking the exams and awarding diplomas or certificates of completion. 
The Udemy platform agrees that teachers sell online courses, withholding $70-85 \%$ of revenue, as well as intellectual property rights.

Coursera found that students who paid symbolic fees of up to $\$ 90$ were more interested in completing the online course and significantly reduced the dropout rate.

Among the limitations of MOOCs we identify: a chaotic learning environment may occur, which does not have a daily or weekly schedule; prior digital education is required for the use of online materials; the effort of the learners and the time allotted for learning may exceed the possibilities of some learners, who need the support of a mentor; students can reshape and reinterpret the course content, without the teacher / instructor / mentor being able to control this (discussion forums are useful for certain topics launched in the debate, but not for a course content); learners need to set their own goals to build their own system of personal resilience and self-regulation; barriers to the translation of the term may arise.

In conclusion, the role of IoT in the education system is major, and the next generation is already prepared with innate or acquired skills to face this new challenge.

The question is what are the positive and negative effects of the intensive and extensive use of technology on the health of the next generation of young people, pupils and students? This may be another research topic for a future article.

\section{REFERENCES}

Adamopoulos, P. (2013). What Makes a Great MOOC? An Interdisciplinary Analysis of Student. Adamopoulos, P. (2013). Retention in Online Courses, ICIS Proceedings pp.1-21 in AIS Electronic Library (AISeL).

Alraimi, K. M., Zo, H., \& Ciganek, A. P. (2015). Understanding the MOOCs continuance: The role of openness and reputation, Computers \& Education. 80, DOI: 10.1016/j.compedu.2014.08.006

Ardis, M. A., \& Henderson, P. B. (2012). Software engineering education (SEEd): is software engineering ready for MOOCs? ACM SIGSOFT Software Engineering Notes, DOI: $10.1145 / 2347696.2347720$

Bell, F. (2011). Connectivism: Its Place in Theory-Informed Research and Innovation in Technology-Enabled Learning. International Review of Research in Open and Distance Learning, 12 (3), DOI: 10.19173/irrodl.v12i3.902

Carr, D. F. (2013). Udacity hedges on open licensing for MOOCs. Information Week. Retrieved September 7, 2014 from: http://www.informationweek.com/software/udacity-hedges-onopenlicensing-for-moocs/d/d-id/1111226?

Creţu, R. F., Anghel, I., \& Curea, C. S. (2013). Quality assurance of the teaching - learning process in Financial Economic Analysis, Journal of Economics and Business Research, 1, pp. 74-83

Curaj, A., Păunică, M., Popa A., Holeab, C., \& Jora, O. D. (2020). Sustainability Through Directed Change in the Visionary University: From Predicting to Producing the Future. Amfiteatru Economic. 22(55). pp. 905-919. DOI: 10.24818/EA/2020/55/905.

Diebold, F. X., \& Kilian, L. (2001). Measuring Predictability: Theory and Macroeconomic Applications, Journal of Applied Econometrics. 16(6): 657-669. doi:10.1002/jae.619.

Dinu, V., Savoiu, Gh., \& Dabija, D. C. (2017). A concepe, a redacta și a publica un articol științific. O abordare în contextul cercetării economice, Ediția a doua, Editura ASE, pp. 21-30.

Downes, S. (2008). CCKO8 - The Distributed Course. The MOOC Guide, September 11.

Greitens, E. (2017). Reziliența, Editura ACT și Politon, p. 19.

Hew, K. F. (2016). Promoting engagement in online courses: What strategies can we learn from three highly rated MOOCS. British Journal of Educational Technology. 47: pp. 320-341.

International Labour Organization, World Economic Forum Jobs of the Future Report; Deloitte, World Economic Forum: Digital Transformation - Retrieved May 5, 2021 from https://www3.weforum.org/docs/WEF_Future_of_Jobs_2020.pdf 
Kaplan, A. M., \& Haenlein, M. (2016). Higher education and the digital revolution: About MOOCs, SPOCs, social media, and the Cookie Monster, Business Horizons. 59(4), 441-450. doi:10.1016/j.bushor.2016.03.008

Pappano, L. (2014). The Year of the MOOC. The New York Times, April 18.

Parr, C. (2013), Mooc creators criticise courses' lack of creativity, Times Higher Education, 1 June, Retrieved May 5, www.timeshighereducation.com

Prpić, J., Melton, J., Taeihagh, A., \& Anderson, T. (2015). MOOCs and crowdsourcing: Massive courses and massive resources. First Monday, 20(12). arXiv:1702.05002. doi:10.5210/fm.v20i12.6143

Saettler, L. P. (1968). A History of Instructional Technology. New York: McGraw Hill.

Semenova, T. V., \& Rudakova, L. M. (2016). Barriers to Taking Massive Open Online Courses (MOOCs). Russian Education \& Society, 58: pp. 228-245.

Șerban, E. C., Hristea, A. M., Curea, Ș. C., \& Crețu, R. F. (2020). Sustainable universities, from indifference to joint action - a panel data analysis, Amfiteatru Economic, 22(54), pp. 376-390. DOI: $10.24818 / \mathrm{EA} / 2020 / 54 / 376$

The Chronicle of Higher Education. In Wikipedia. Retrieved July 13, 2021 from https://en.wikipedia.org/wiki/The_Chronicle_of_Higher_Education.

Vihavainen, A., Luukkainen, M., \& Kurhila, J. (2012). Multi-faceted support for MOOC in programming. Proceedings of the 13th annual conference on Information technology education - SIGITE '12. p. 171. doi:10.1145/2380552.2380603

Yousef, A. M. F., Chatti, M. A., Schroeder, U., Wosnitza, M., \& Jakobs, H. (2015). The State of MOOCs from 2008 to 2014: A Critical Analysis and Future Visions, International Conference on Computer Supported Education, CSEDU 2014: Computer Supported Education pp 305-327, DOI: $10.1007 / 978-3-319-25768-6 \_20$

\section{Annex 1}

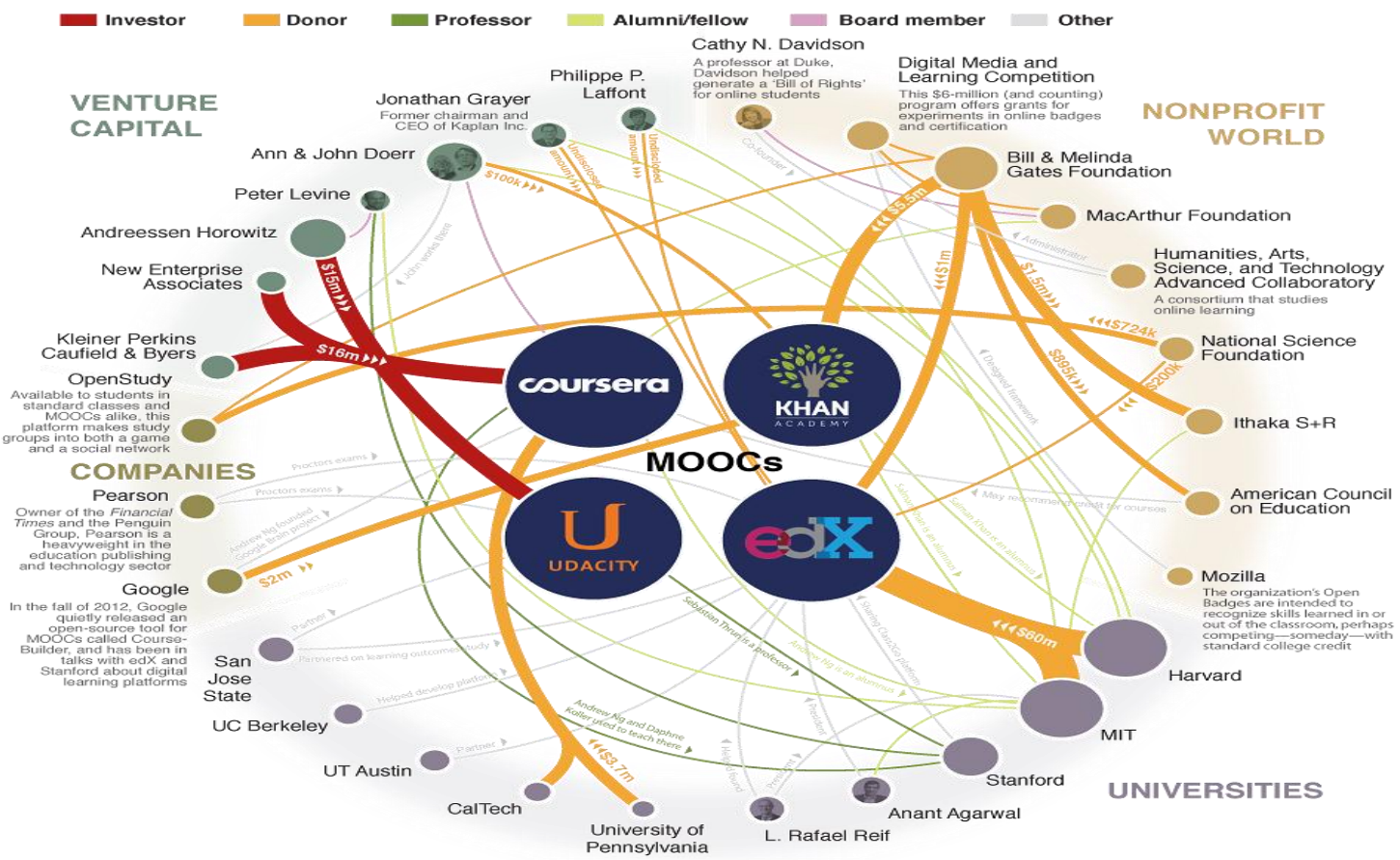

Source: Major Players in the MOOC Universe (chronicle.com) 


\section{Annex 2}

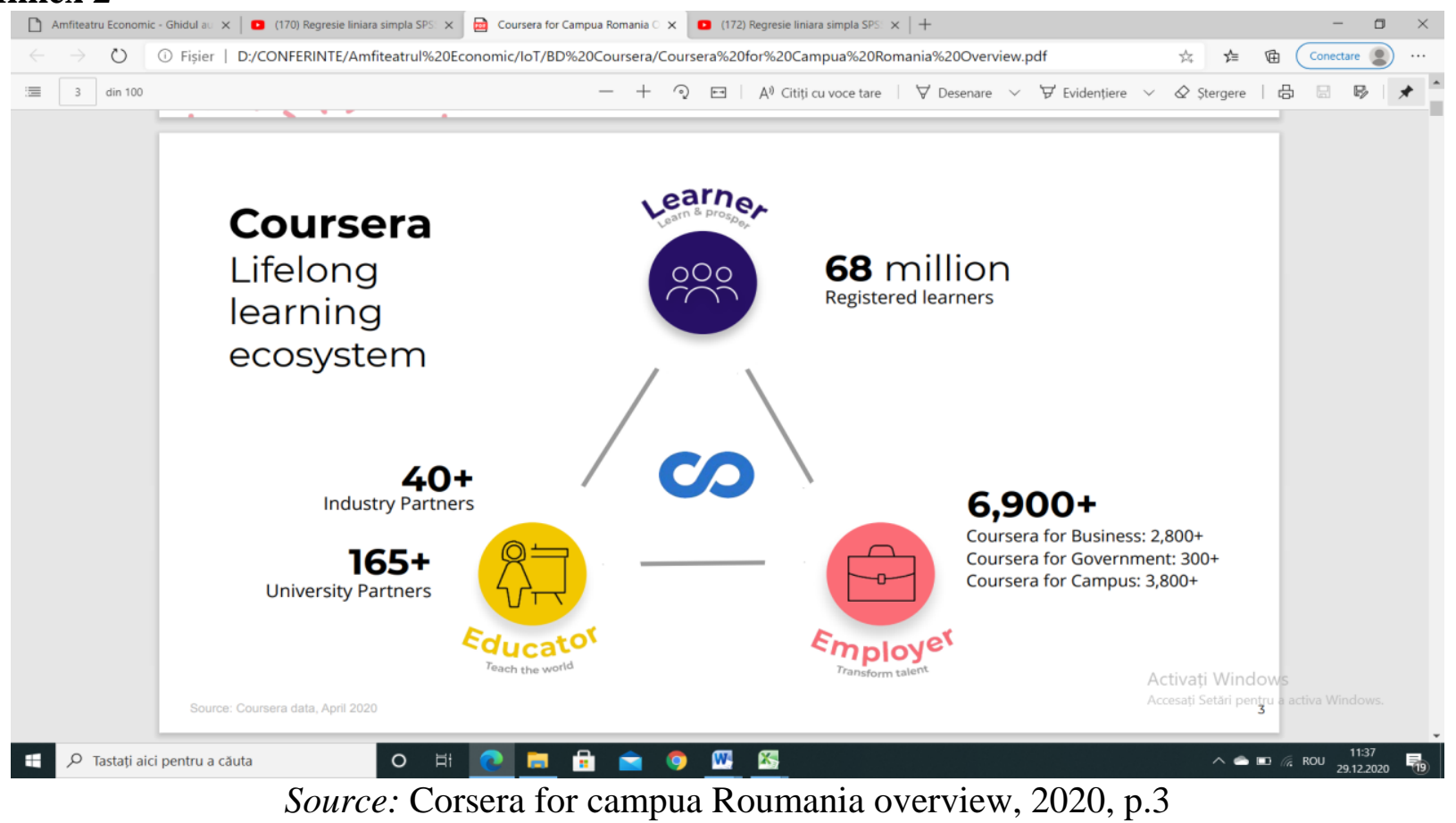

\section{Annex 3}

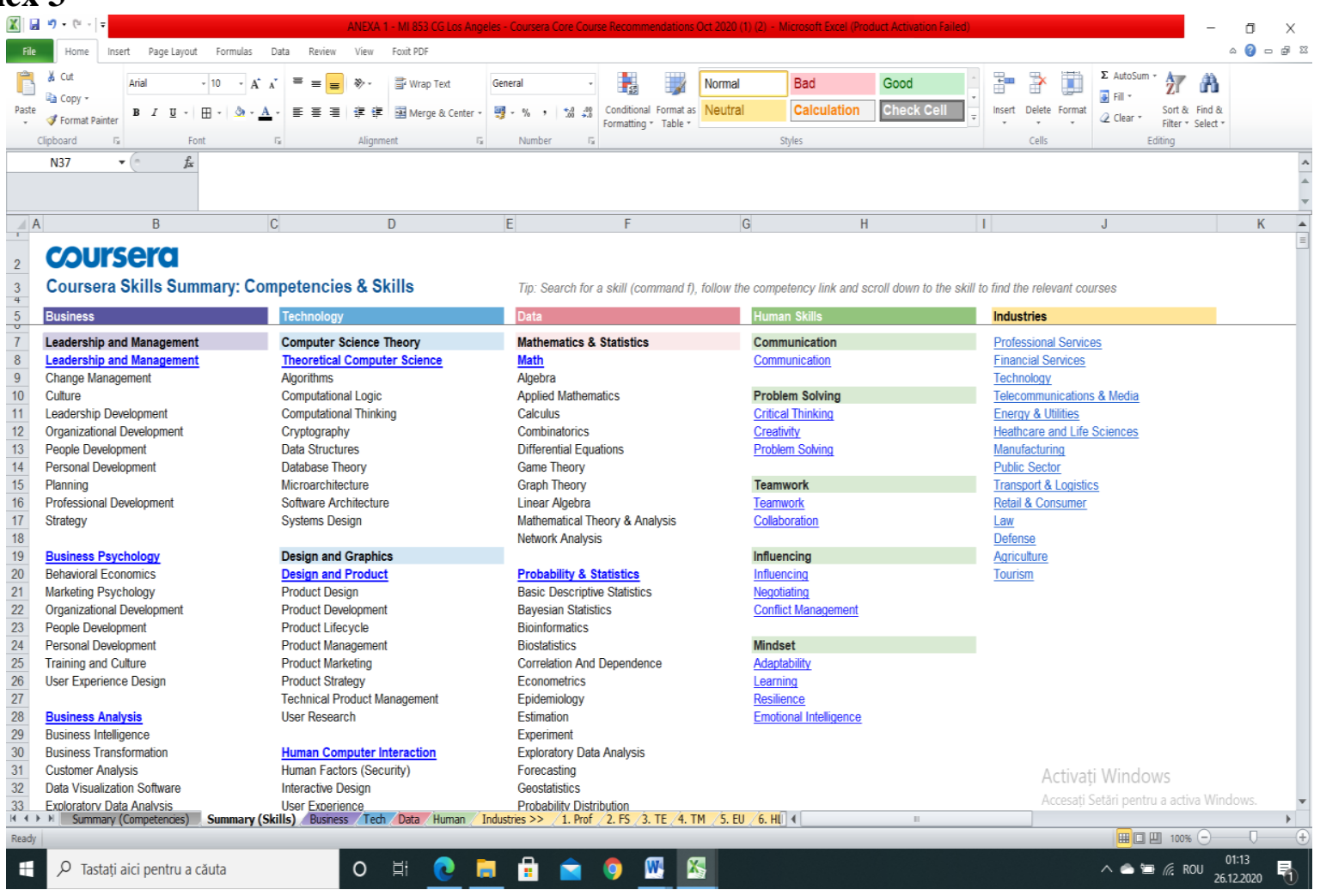

Source: MI 853 CG Los Angeles - Coursera Core Course Recommandations iunie 2020 


\section{Annex 4}

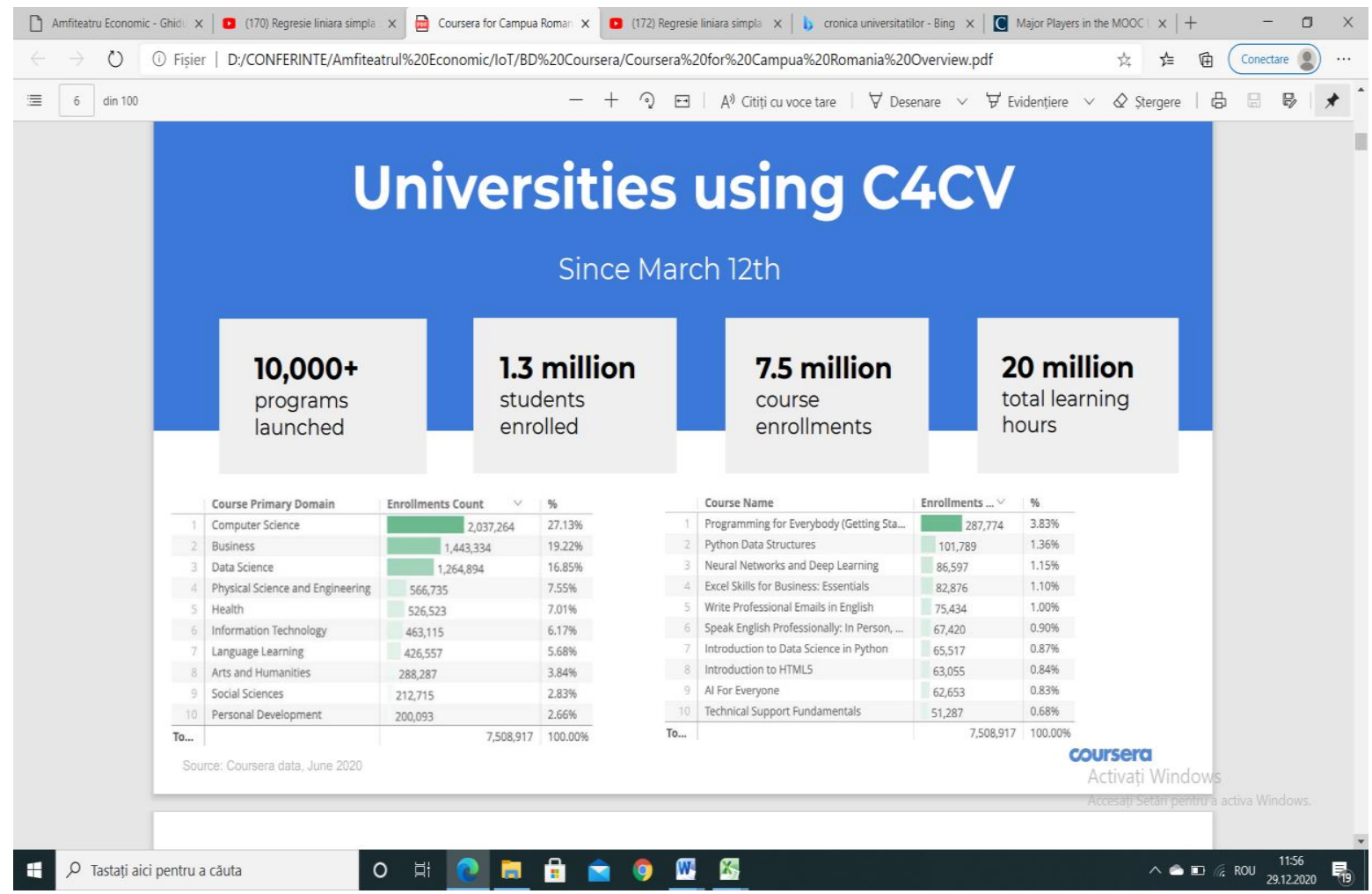

Source: Corsera for campua Roumania overview, 2020, p.6

\section{Annex 5}

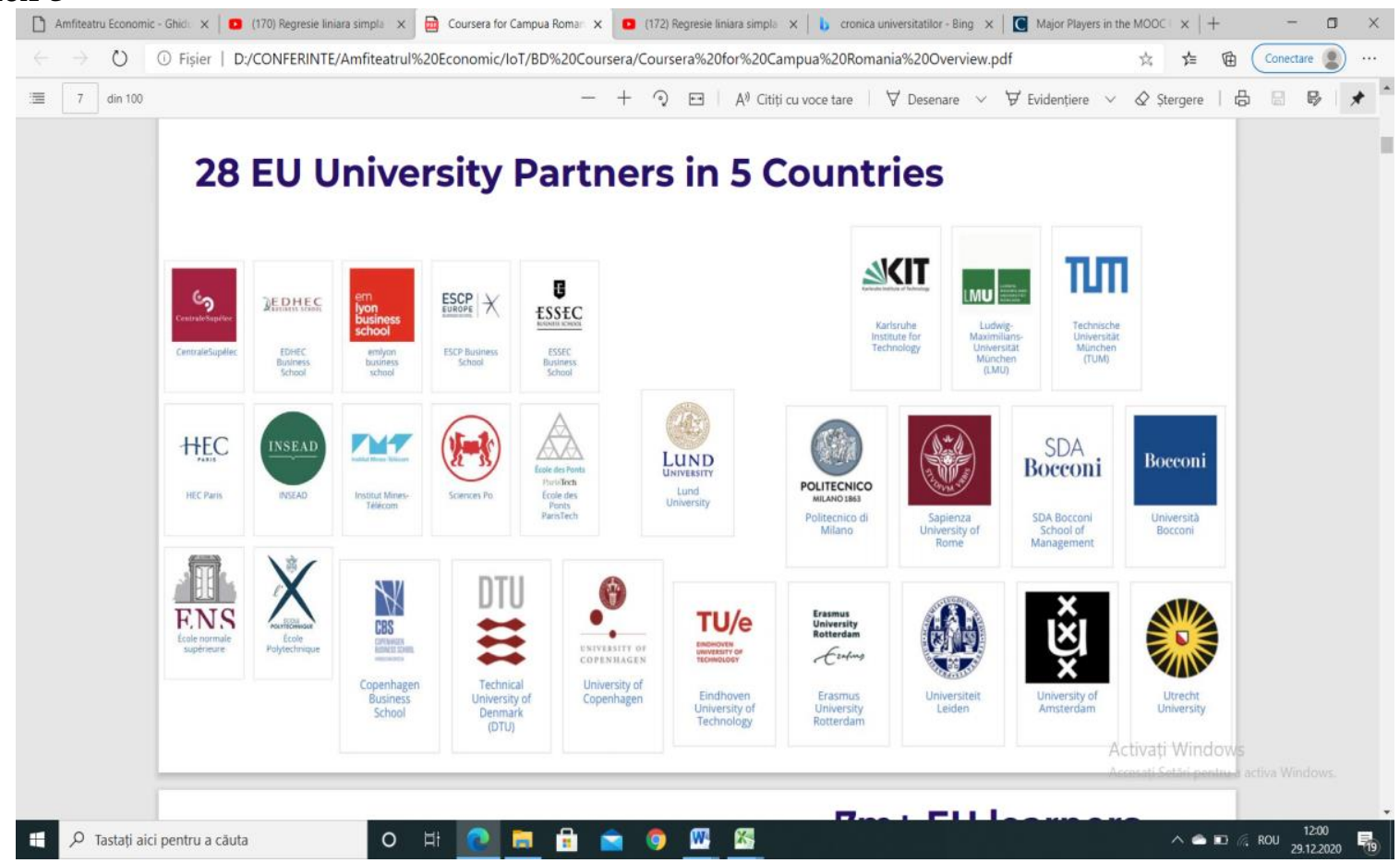

Source: Corsera for campua Roumania overview, 2020, p.7 


\section{Annex 6}

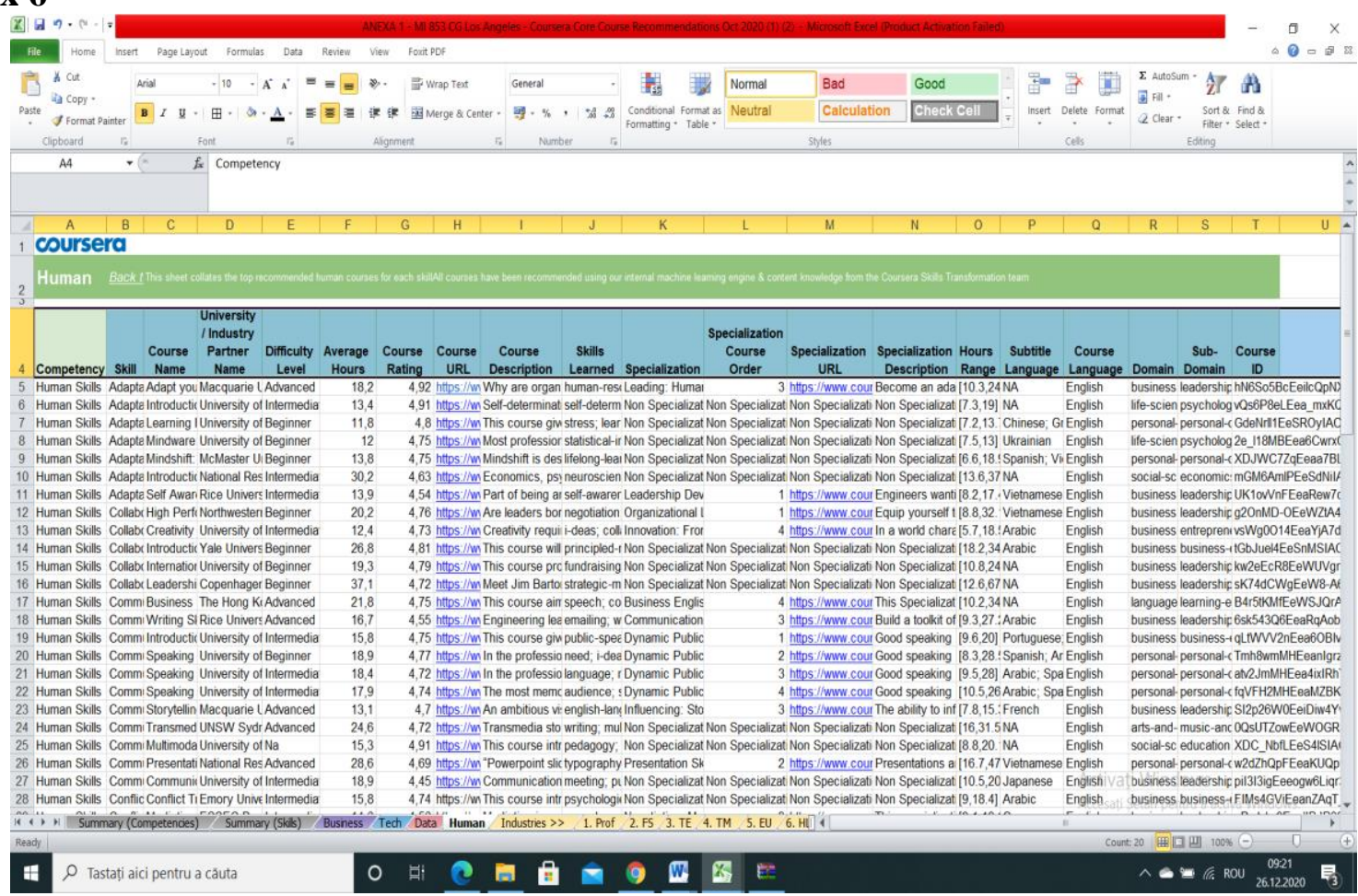

Source: MI 853 CG Los Angeles - Coursera Core Course Recommandations iunie 2020 